\title{
Seasonality of occurrence and recruitment of Arctic marine benthic invertebrate larvae in relation to environmental variables
}

\author{
Piotr Kuklinski • Jørgen Berge $•$ Laurel McFadden • \\ Katarzyna Dmoch • Marek Zajaczkowski • \\ Henrik Nygård $\cdot$ Kasia Piwosz $\cdot$ Agnieszka Tatarek
}

Received: 1 March 2012/Revised: 12 December 2012/ Accepted: 29 December 2012/Published online: 19 January 2013

(C) The Author(s) 2013. This article is published with open access at Springerlink.com

\begin{abstract}
The Arctic system is one of the regions most influenced by ongoing global climate change, but there are still critical gaps in our knowledge regarding a substantial number of biological processes. This is especially true for processes taking place during the Arctic winter but also for seasonal processes, such as the dynamics of intra-annual meroplankton occurrence. Here, we report on a 1-year study of meroplankton seasonal variability from a fjordic system in the Arctic Archipelago of Svalbard. The study combines an examination of phytoplankton, zooplankton, and hard bottom benthic settlement with measurements of environmental parameters (e.g., water temperature, particulate organic matter, and dissolved organic carbon).
\end{abstract}

P. Kuklinski $(\bowtie) \cdot$ K. Dmoch · M. Zajaczkowski · A. Tatarek Institute of Oceanology, Polish Academy of Sciences, ul. Powstanców Warszawy 55, 81-712 Sopot, Poland e-mail: kuki@iopan.gda.pl

P. Kuklinski

Natural History Museum, Cromwell Road,

London SW7-5BD, UK

J. Berge $\cdot$ H. Nygård

The University Center in Svalbard, P.O. Box 156,

9171 Longyearbyen, Norway

J. Berge

Faculty of Biosciences, Fisheries and Economics,

University of Tromsø, 9037 Tromsö, Norway

L. McFadden

Prince William Sound Science Center, P.O. Box 1631,

Cordova, AK 99574, USA

K. Piwosz

National Marine Fisheries Research Institute, ul. Kołłataja 1,

81-332 Gdynia, Poland
Samples were taken on a bi-weekly or monthly basis, and a total of 11 taxa representing six phyla of meroplankton were recorded over a 1-year period from January to December 2007. The occurrence of benthic larvae varied between the seasons, reaching a maximum in both abundance and taxon richness in late spring through early summer. Meroplanktonic larvae were absent in winter. However, settlement of benthic organisms was also recorded during the winter months (February and March), which indicates individual trade-offs related to timing of reproduction and competition. In addition, it suggests that these larvae are not relying on higher summer nutrient concentrations, but instead are dependent on alternative food sources. In parallel with meroplankton abundance, all other measured parameters, both biological (e.g., phyto- and zooplankton abundance and diversity) and physical (e.g., particulate organic matter), exhibited seasonal variability with peaks in the warmer months of the year.

Keywords Arctic - Seasonality $\cdot$ Phytoplankton · Meroplankton · Holoplankton · Benthos · Settlement

\section{Introduction}

The Arctic is one of the regions most influenced by ongoing global climate change (IPCC 2007). Despite the enormous pressure on polar systems caused by factors which include increasing seawater temperature and the disappearance of the permanent ice, we still do not have sufficient knowledge about the current state of a number of biological processes (see e.g., Berge et al. 2012). Some examples are the intra-annual seasonality of meroplankton occurrence, timing of benthic organisms' recruitment, and the factors driving their abundance. 
Larval dispersal away from maternal populations enables organisms to avoid inbreeding and is an important factor for maintaining genetic diversity (Grosberg and Quinn 1986). Colonization of new areas may also lower intra-specific food competition between individuals. Survival and distribution are largely dependent on water column processes, and range requirements for water temperature, salinity, and type of food by larvae are often considered to be narrower than those of the adult organisms (Thorson 1950; Calabreses and Davis 1970). Larval stages are thus often the most sensitive stage in the life cycle of many benthic organisms.

Although the importance of the larval phase for benthic organisms is recognized, little attention has been paid to meroplankton ecology, in particular in the Arctic. Since the first study of Arctic meroplankton by Thorson (1936), only a few and mostly recent studies have focused on the occurrence of meroplankton in relation to environmental conditions (Mileikovsky 1968; Andersen 1984; Clough et al. 1997; Timofeev 1998; Schlüter and Rachor 2001; Fetzer and Deubel 2006; Fetzer and Arntz 2008). Some information on meroplankton spatial and temporal distribution has been provided by investigations of Arctic macrozooplankton (Willis et al. 2006; Walkusz et al. 2009) or seasonality of ecosystems at local functional levels (e.g., zooplankton, phytoplankton) (Point Barrow AlaskaMacGinitie 1955; Spitsbergen-Weslawski et al. 1988, 1991). At present, it is accepted that the Arctic currents might govern meroplankton distribution (Mileikovsky 1968; Clough et al. 1997; Schlüter and Rachor 2001). However, biological processes taking place in the water column (e.g., phytoplankton blooms) also seems to influence meroplanktonic abundance (Willis et al. 2006). Some meroplankton species (cirripeds, polychaetes) were present in an Arctic ecosystem starting at the end of April and lasting throughout June (Willis et al. 2006; Walkusz et al. 2009). The appearance of meroplankton immediately followed the spring phytoplankton bloom (mid to late April), suggesting a link between these phenomena. There are also indications that the local species pool of adult organisms on the sea floor plays a crucial role in the invertebrate larval species composition and abundance observed in the water column (Mileikovsky 1968; Clough et al. 1997). While there are some data on intra-annual meroplankton dynamics (e.g., Thorson 1936; Andersen 1984), studies on seasonal variation of meroplankton above the Arctic circle over an entire year are, to our knowledge, lacking. More numerous Antarctic studies revealed a high diversity of meroplankton often exceeding one hundred taxa (StanwellSmith et al. 1999; Bowden et al. 2009). Investigations on invertebrate larvae in the Antarctic show pronounced seasonality in their abundance and taxon composition (Stanwell-Smith et al. 1999; Bowden et al. 2009). Both number of taxa and individuals were highest during austral summer (Stanwell-Smith et al. 1999; Bowden et al. 2009). In the Arctic, as in other strongly seasonal environments (sub-Arctic, Antarctic), we expect meroplankton larvae presence and abundance to have defined periods of occurrence linked to seasonally fluctuating resources (e.g., food).

Understanding meroplankton variability over all seasons will help reveal breeding strategies of benthic organisms, which for many Arctic species remains virtually unknown. Meroplankton differences in timing and longevity of occurrence in the water column suggest that these strategies can be very complex. The concept of capital and income breeding was first introduced by Drent and Daan (1980) and then modified by Stearns (1992). The capital breeder is defined as an organism that uses stored energy for reproduction. In contrast, the income breeder relies on energy obtained during the reproductive period rather than stored energy. This concept is based on vertebrate life history, but it has a broad application across all phyla including marine invertebrates (see Varpe et al. 2009; Nygård et al. 2010). Theoretically, for Arctic benthic organisms with planktotrophic larvae feeding in the water column, the most beneficial timing for reproduction would be just prior to the period of highest food abundance, assuming that the phytoplankton bloom is the primary food source. For organisms with lecitotrophic larvae, which are less dependent on water column resources, reproduction and settlement would be most beneficial prior to the phytoplankton bloom. Settled larvae would benefit from the occurrence of very abundant phytoplankton resources, increasing their fitness and chances of survival during the polar night, when food resources are limited or essentially absent. However, limited information (e.g., Willis et al. 2006; Piwosz et al. 2009; Walkusz et al. 2009) indicate that Arctic meroplankton occur both during the polar summer and autumn, long after phytoplankton peak abundance. We therefore predict that Arctic benthic organisms especially from the area covered by this study (Adventfjorden) have complex breeding strategies that include both capital and income breeders.

Here, we present an investigation of meroplankton conducted over a 1-year period in a fjord of the high Arctic archipelago of Svalbard, combining examinations of phytoplankton (potential food of meroplankton) and holoplankton (potential predators of meroplankton) with a hard bottom settlement experiment. We also monitored environmental conditions including water temperature, particulate organic matter, and dissolved organic carbon. These environmental data allowed us to pinpoint some of the factors triggering the occurrence of meroplankton, as well as exclude some factors that do not influence invertebrate larvae in the water column. The settlement experiment not only enabled us to couple the duration of larval occurrence 
in the water column with estimates of settlement timing, but also gives us insight into the seasonality of colonization by benthic organisms.

\section{Materials and methods}

\section{Study area}

Adventfjorden is a small fjord $8.3 \mathrm{~km}$ long and $3.4 \mathrm{~km}$ wide extending from Isfjorden on the west coast of Spitsbergen (Fig. 1). The fjord reaches its maximum depth of around $100 \mathrm{~m}$ at the mouth and is strongly influenced by the water masses of Isfjorden and by two rivers (Adventdalselva and Longyeardalselva). Water temperatures in the fjord range annually from -1 to $7^{\circ} \mathrm{C}$ (Zajaczkowski et al. 2010). Salinity is variable due to high freshwater discharge from the rivers, ranging between 5 and 34 psu (Zajaczkowski et al. 2010). The suspension load brought into the fjord by the two rivers can reach more than $300 \mathrm{mg} \mathrm{dm}^{-3}$ in the peak summer melting season (Zajaczkowski and WlodarskaKowalczuk 2007). In winter, the supply of terrigenous material to the fjord stops, as the rivers are frozen and the surface of the fjord is usually covered by fast ice. The bottom of the fjord is dominated by soft sediments. Macrobenthic communities in the fjord are dominated by soft bottom polychaetes and mollusks (Pawlowska et al. 2011), with patches of hard bottom fauna as well as a number of man-made constructions with associated rocky bottom habitat fauna including cirripeds, ascidians, and bryozoans (pers. observations). In the vicinity of the sampling sites in Isfjorden, there are large species pools of hard bottom fauna (pers. observations).

Two sampling sites (A and B, Fig. 1) approximately $1 \mathrm{~km}$ apart from each other were chosen for year-round

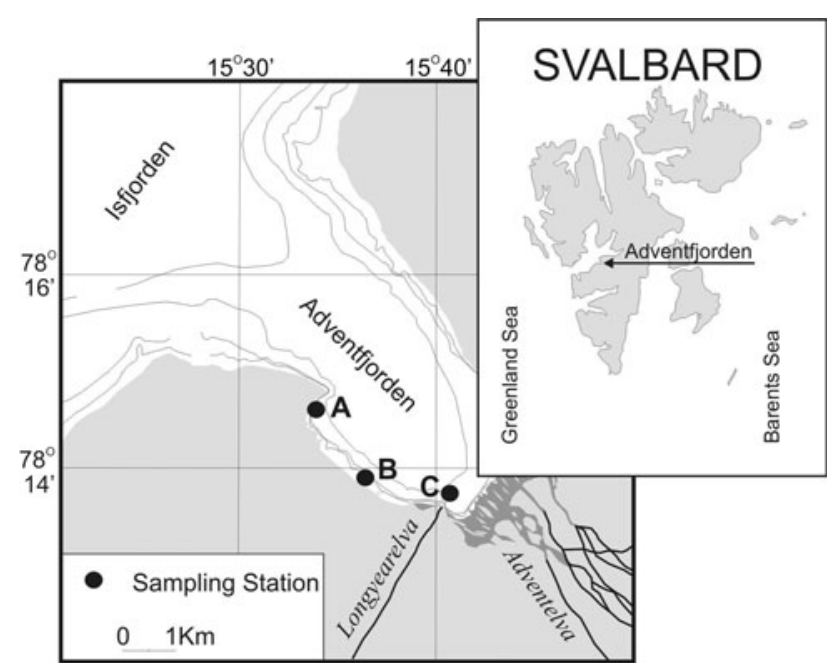

Fig. 1 Study site showing sampling locations sampling access near to the town of Longyearbyen. Additional environmental data were also gathered at station $\mathrm{C}$ located east of station B, approximately $1 \mathrm{~km}$ apart from both stations, A and B (Fig. 1).

Plankton sampling and laboratory analysis

Each of the sites was sampled from January to December 2007 using a $10 \mathrm{dm}^{3}$ water sampler deployed near the ocean floor (at $\sim 6 \mathrm{~m}$ depth). Such sampling aimed at catchment of demersal larvae of benthic organisms which are hardly ever present in water column plankton samples. Sampling rates early in the year were on a bi-weekly scheduled, later (from August) the sampling rate was shifted to a monthly schedule. Water samples were sieved through a phytoplankton net with a mesh size of $20 \mu \mathrm{m}$ that allowed the capture of even very small larvae of benthic invertebrates. Sieved samples were immediately preserved in a buffered $4 \%$ formaldehyde-seawater solution for later examination. Both phyto- and zooplankton (holo- and meroplankton) were counted and identified to the lowest taxonomic level possible using a microscope and stereomicroscope. All abundance data of meroplankton from the $10 \mathrm{dm}^{3}$ water sampler were scaled up to $1 \mathrm{~m}^{3}$.

\section{Settlement study}

At each of the sites, two sets of settlement panels (three Perspex plates $15 \times 15 \mathrm{~cm}$ in each set, $2 \mathrm{~cm}$ space between each plate) were deployed vertically from the pier above the sea floor at a depth of $\sim 6 \mathrm{~m}$. Panels were mounted to metal construction, which ensure their rigidity. Panels exchange was done from the pier with use of rope attached to the construction. One of the sets was left as a control/ reference for taxonomical investigations for the duration of the study period (1 year), while the other set of panels was changed according to the sampling schedule (bi-weekly to monthly, see above). Once retrieved, panels were taken into the laboratory for examination. Only one side of the panels was analyzed $\left(225 \mathrm{~cm}^{2}\right)$ as the mounting bars obstructed the other side surface and thus not fully exposed for colonization. All organisms on the panel were counted and identified to the lowest possible taxonomical level using a stereomicroscope. As most samples contained the juvenile forms of benthic organisms, the taxonomical resolution was often restricted to the phylum or class level (e.g., Hydrozoa, Bryozoa).

Environmental variables

At each location, salinity and water temperature were measured using a Star-Oddi data logger. Measurements were set at $30 \mathrm{~min}$ intervals throughout the study period. 
Unfortunately, data from station B were impossible to retrieve due to a malfunction with the logger. Environmental variables including total particulate matter (TPM), particulate inorganic matter (PIM), particulate organic matter (POM), particulate organic carbon (POC), particulate organic nitrogen (PON), dissolved organic carbon (DOC), Chlorophyll a (Chl a), and phaeopigments (Phaeo) were measured at station $\mathrm{C}$ at $5 \mathrm{~m}$ depth. These measurements were taken six times over the year (06 Feb, 17 Apr, 22 May, 12 Jul, 14 Aug, and 24 Oct). For detailed methodology on sampling and laboratory analysis see Zajaczkowski et al. (2010). Ice cover was estimated visually and recorded during each plankton water sampling.

Data analysis

The PRIMER software package was used to compare meroplankton faunal composition between different seasons and sites. Based on a quantitative square root-transformed data matrix, the Bray-Curtis similarity measure for meroplankton composition was calculated (Bray and Curtis 1957). The inter-relationship between samples was mapped using the ordination technique with non-metric, multidimensional scaling (nMDS). Samples where no larvae were present were not included in the nMDS analysis.

We used a one-way analysis of similarities (ANOSIM) to explore differences in assemblages of meroplankton and on settlement panels between the two investigated sites. The analysis was based on Bray-Curtis rank similarities between samples, calculated from square root-transformed abundance data.

Variability among abundance and taxon richness of meroplankton and on settlement panels between the sites were identified using a one-way analysis of variance (ANOVA). ANOVA was followed by a $\log (x+1)$ data transformation to improve normality and homogeneity. Homogeneity was achieved for all sets of data (Levene's test: meroplankton taxa richness $F>0.01, p=0.993$; meroplankton abundance $F=0.264, p=0.609$; taxa richness on the settlement panels $F=0.28, p=0.592$; abundance on the settlement panels $F=0.03, p=0.848$ ). ANOVA analysis and all plots were done with the use of Statistica 8.0 Software.

\section{Results}

Diversity and seasonality of mero-, phyto-, holoplankton, and settlement

A total of 34 water samples were analyzed (17 samples each from locations A and B, see Fig. 1) over a 12-month period. In total 11 meroplanktonic taxa were recorded
(11 at stn A, nine at stn B) representing at least six phyla (Table 1). In total, meroplankton diversity over a year constituted $31 \%$ of holoplankton taxa richness (36 taxa) and $50 \%$ of that observed on settlement panels (22 taxa).

The occurrence of benthic larvae varied between the seasons (Fig. 2). The highest total number of larvae was recorded in May at station $\mathrm{B}\left(22,200\right.$ indiv. $\left.\mathrm{m}^{-3}\right)$ and in June at station A (43,900 indiv. $\left.\mathrm{m}^{-3}\right)$ (Fig. 2). During the winter months, from January until the end of March, no larvae were recorded in the water samples. Larvae first appeared in the water column at the end of March. From March on, the species richness gradually increased, reaching its maximum at station $\mathrm{A}$ at the end of April (five taxa) and at station B at the beginning of May (seven taxa) (Fig. 2). For some meroplankton taxa including Gastropoda and Echinodermata, seasonality of occurrence was very pronounced (Fig. 3). The majority of taxa had one distinct peak of abundance; however, taxa such as Bryozoa, Bivalvia and some Polychaeta had at least two peaks of abundance during the year (Fig. 3). The most abundant larvae were Cirripedia, reaching 35,900 indiv. $\mathrm{m}^{-3}$ at stn $\mathrm{A}$ in June. The second most abundant were Bivalvia veligers reaching 14,700 indiv. $\mathrm{m}^{-3}$ at the end of June at stn $\mathrm{B}$. The least abundant taxa were Bryozoa cyphonautes larvae, Gastropoda, and Polychaeta with 100 indiv. $\mathrm{m}^{-3}$ at their maximum of abundance (June, August-September, and March, respectively) (Fig. 3).

The meroplankton taxonomic composition changed during the year (Fig. 4). Early spring assemblages were dominated by Polychaeta and Cirripedia larvae, while late summer/early autumn assemblages were dominated by mollusks.

Phytoplankton and holoplankton were observed in the water column throughout the year (Fig. 2). However, phytoplankton had a distinct peak of abundance in spring (April), while the holoplankton abundance peak followed and reached its maximum in May ( $\operatorname{stn}$ B) and June (stn A). The number of phytoplankton taxa was highest in April (stn A - 27 taxa, stn B - 31 taxa). Patterns in holoplankton taxa number varied throughout the year, with peak values reached in June (stn A - 15 taxa, stn B - 11 taxa) (Fig. 2).

During the course of the year, we recorded 22 taxa on settlement panels (17 taxa on panels deployed for the entire study period and seven on the biweekly or monthly deployed panels) (Table 1). Bryozoans were the most species-rich group with 13 taxa recorded, while Hydrozoa, Copepoda, Ascidiacea, and Echinodermata were represented by only one taxon each (Table 1). Larvae first appeared on the settlement panels in February (spirorbid polychaetes, stn A). Hydrozoa, cheilostome bryozoans and spirorbid polychaetes were the last organisms to appear on the panels (November) during the study year. Unfortunately, we had no panels deployed in December. The 
Table 1 Taxa of meroplankton present in water column and benthic taxa present on bi-weekly/monthly-changed settlement panels as well as on the settlement panels deployed as a controlled for 1 year from

\begin{tabular}{|c|c|c|c|c|c|c|c|}
\hline \multirow[t]{3}{*}{ Group } & \multirow[t]{3}{*}{ Taxa (larvae type) } & \multicolumn{3}{|l|}{ Stn A } & \multicolumn{3}{|l|}{ Stn B } \\
\hline & & \multirow{2}{*}{$\begin{array}{l}\text { Meroplankton in } \\
\text { water column }\end{array}$} & \multicolumn{2}{|l|}{ Panels } & \multirow{2}{*}{$\begin{array}{l}\text { Meroplankton in } \\
\text { water column }\end{array}$} & \multicolumn{2}{|l|}{ Panels } \\
\hline & & & Seasonal & After one year & & Seasonal & After one year \\
\hline \multirow[t]{6}{*}{ Polychaeta } & Circesi spirulum $(\mathbf{L})$ & & & & & & $\mathrm{x}$ \\
\hline & Sabellidae indet. (?) & & & & & & $\mathrm{x}$ \\
\hline & Spirorbidae indet. (L) & & $\mathrm{x}$ & & & $\mathrm{x}$ & \\
\hline & Spionidae indet. (P?) & $\mathrm{x}$ & & & $\mathrm{x}$ & & \\
\hline & Trochophorae indet. (P) & $\mathrm{x}$ & & & $\mathrm{x}$ & & \\
\hline & Larvae indet. (?) & & & & $\mathrm{x}$ & & \\
\hline Hydrozoa & Hydrozoa indet. (?) & & $\mathrm{x}$ & & & $\mathrm{x}$ & \\
\hline Copepoda & Harpacticoida indet. (?) & & $\mathrm{x}$ & $\mathrm{x}$ & & $\mathrm{x}$ & \\
\hline Ascidiacea & Ascidiacea indet. (?) & & $\mathrm{x}$ & & & & \\
\hline \multirow[t]{2}{*}{ Crustacea } & Semibalanus balanoides $(\mathbf{P})$ & & $\mathrm{x}$ & $\mathrm{x}$ & & $\mathrm{x}$ & $\mathrm{x}$ \\
\hline & Cirripedia indet. (P) & $x$ & & & $\mathrm{x}$ & & \\
\hline \multirow[t]{5}{*}{ Mollusca } & Hiatella cf. arctica (?) & & & $\mathrm{x}$ & & & $\mathrm{x}$ \\
\hline & Bivalvia indet. (?) & & $\mathrm{x}$ & & & & \\
\hline & Bivalvia veliger $(\mathbf{P})$ & $\mathrm{x}$ & & & $\mathrm{x}$ & & \\
\hline & Bivalvia larvae indet. (?) & $\mathrm{x}$ & & & $\mathrm{x}$ & & \\
\hline & Gastropoda larvae indet. (?) & $\mathrm{x}$ & & & $\mathrm{x}$ & & \\
\hline Echinodermata & Larvae indet. & $\mathrm{x}$ & & & & & \\
\hline \multirow[t]{15}{*}{ Bryozoa } & Callopora craticula $(\mathbf{L})$ & & & & & & $\mathrm{x}$ \\
\hline & Celleporella hyalina $(\mathbf{L})$ & & & $\mathrm{x}$ & & & $\mathrm{x}$ \\
\hline & Cribrilina annulata $(\mathbf{L})$ & & & $\mathrm{x}$ & & & $\mathrm{x}$ \\
\hline & Crisiella sp. (L) & & & & & & $\mathrm{x}$ \\
\hline & Dendrobeania sp. (L) & & & $\mathrm{x}$ & & & $\mathrm{x}$ \\
\hline & Harmeria scutulata $(\mathbf{L})$ & & & $\mathrm{x}$ & & & $\mathrm{x}$ \\
\hline & Patinella sp. (L) & & & $\mathrm{x}$ & & & $\mathrm{x}$ \\
\hline & Porella alba $(\mathbf{L})$ & & & & & & $\mathrm{x}$ \\
\hline & Scrupocellaria cf. arctica $(\mathbf{L})$ & & & $\mathrm{x}$ & & & $\mathrm{x}$ \\
\hline & Scrupocellaria cf. scabra (L) & & & & & & $\mathrm{x}$ \\
\hline & Tegella arctica $(\mathbf{L})$ & & & $\mathrm{x}$ & & & $\mathrm{x}$ \\
\hline & Tegella armifera $(\mathbf{L})$ & & & & & & $\mathrm{x}$ \\
\hline & Cheilostomata indet. (?) & & $\mathrm{x}$ & & & $\mathrm{x}$ & \\
\hline & Cyphonautes larvae (P) & $\mathrm{x}$ & & & $\mathrm{x}$ & & \\
\hline & Larvae indet. (?) & $\mathrm{x}$ & & & $\mathrm{x}$ & & \\
\hline \multirow[t]{3}{*}{ Larvae indet. } & Trochophorae indet. I (?) & $\mathrm{x}$ & & & $\mathrm{x}$ & & \\
\hline & Trochophorae indet. II (?) & $\mathrm{x}$ & & & & & \\
\hline & Trochophorae indet. III (?) & $\mathrm{x}$ & & & $\mathrm{x}$ & & \\
\hline
\end{tabular}

two study locations A and B (larvae type: $L$ lecitotrophic, $P$ planktotrophic, ? - unknown) 
Fig. 2 Diversity and abundance of phyto-, holo-, and meroplankton as well as organisms on settlement panels at stn A and B. Bars represent standard deviation. Note that phyto-, holo-, and meroplankton abundance data are presented per sample which was volume of the water sampler $\left(10 \mathrm{dm}^{3}\right)$
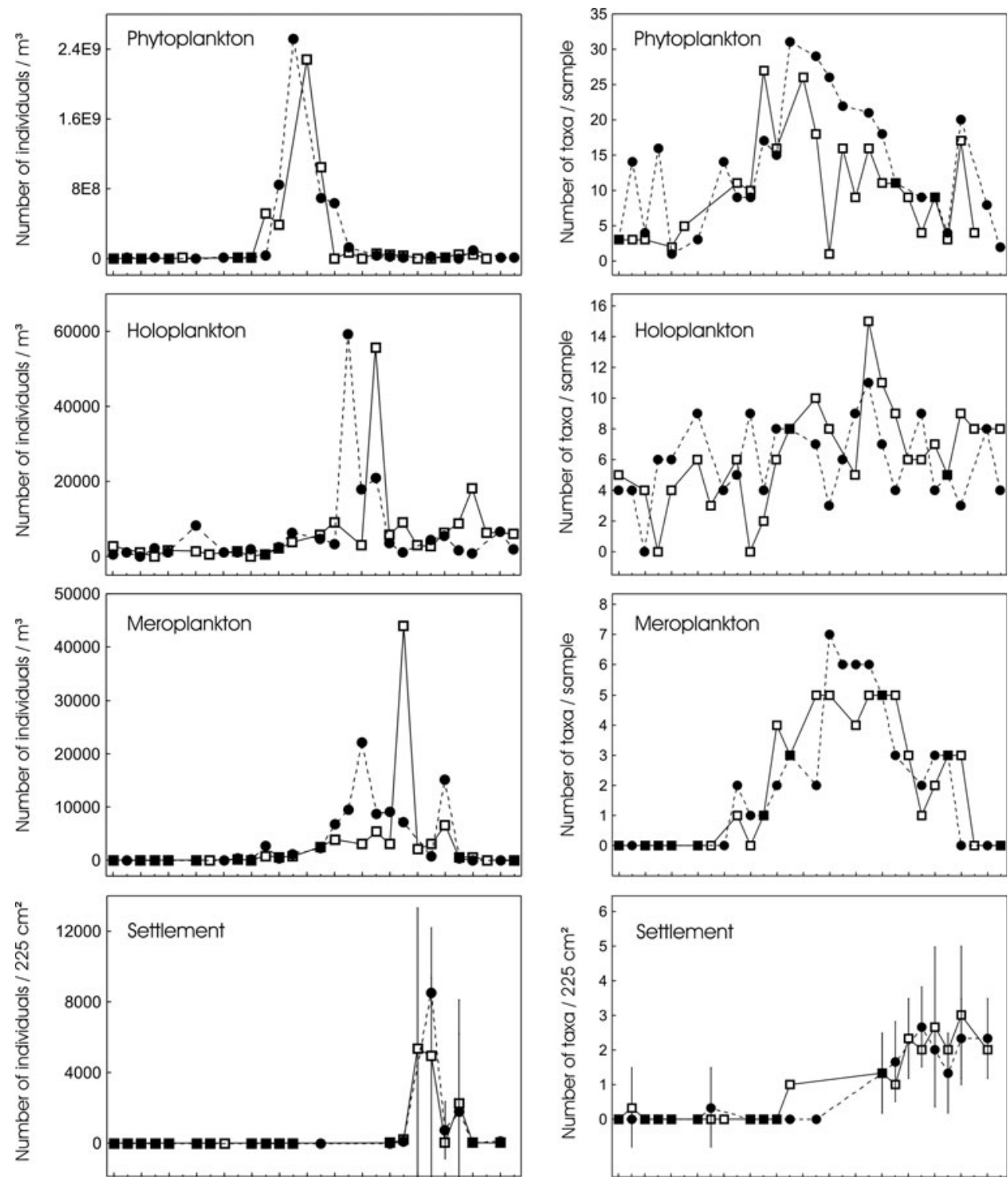

ลิ

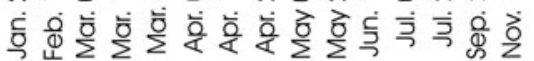

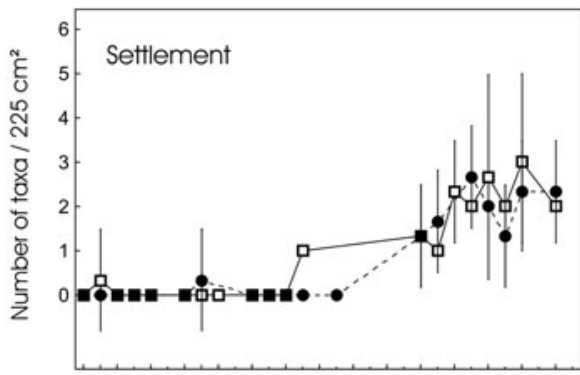

ลำำสำำลำำส

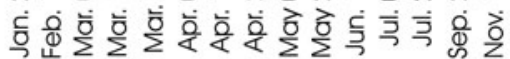

- $\operatorname{Stn} A \quad \operatorname{Stn} B$

$p=0.356)$. Similarly, no statistically significant differences were found between the two stations for abundance of meroplankton $\left(F_{(1,47)}>0.01, p=0.984\right)$ or settled taxa $\left(F_{(1,45)}=0.21, p=0.643\right)$. ANOSIM tests indicated no difference in species composition of meroplankton $(R=$ $-0.045, p=0.954)$ or between settled taxa $(R=-0.062$, $p=0.739$ ) among stations A and B. This was also confirmed for meroplankton assemblages by a MDS plot. The MDS analysis revealed similar patterns for samples from both sites where species composition followed changes from early spring to autumn (Fig. 4). The similarity of the results indicates reasonable homogeneity of environmental conditions for the study area that therefore allows us to use environmental variable measurements taken from a nearby location.

Environmental variables

All measured environmental variables varied seasonally (Fig. 5). Sea water temperatures were highest during the summer months, reaching up to $8.3^{\circ} \mathrm{C}$ in July, and were lowest in winter (February) and spring months (April), reaching $-1.5^{\circ}$ C. Salinity was lowest in July and August. While total particulate matter (TPM), particulate inorganic matter (PIM), and particulate organic nitrogen (PON) reached their maxima during the summer months, other 
Fig. 3 Seasonal abundance of benthic invertebrate larvae in the water column at stn $\mathrm{A}$ and $\mathrm{B}$

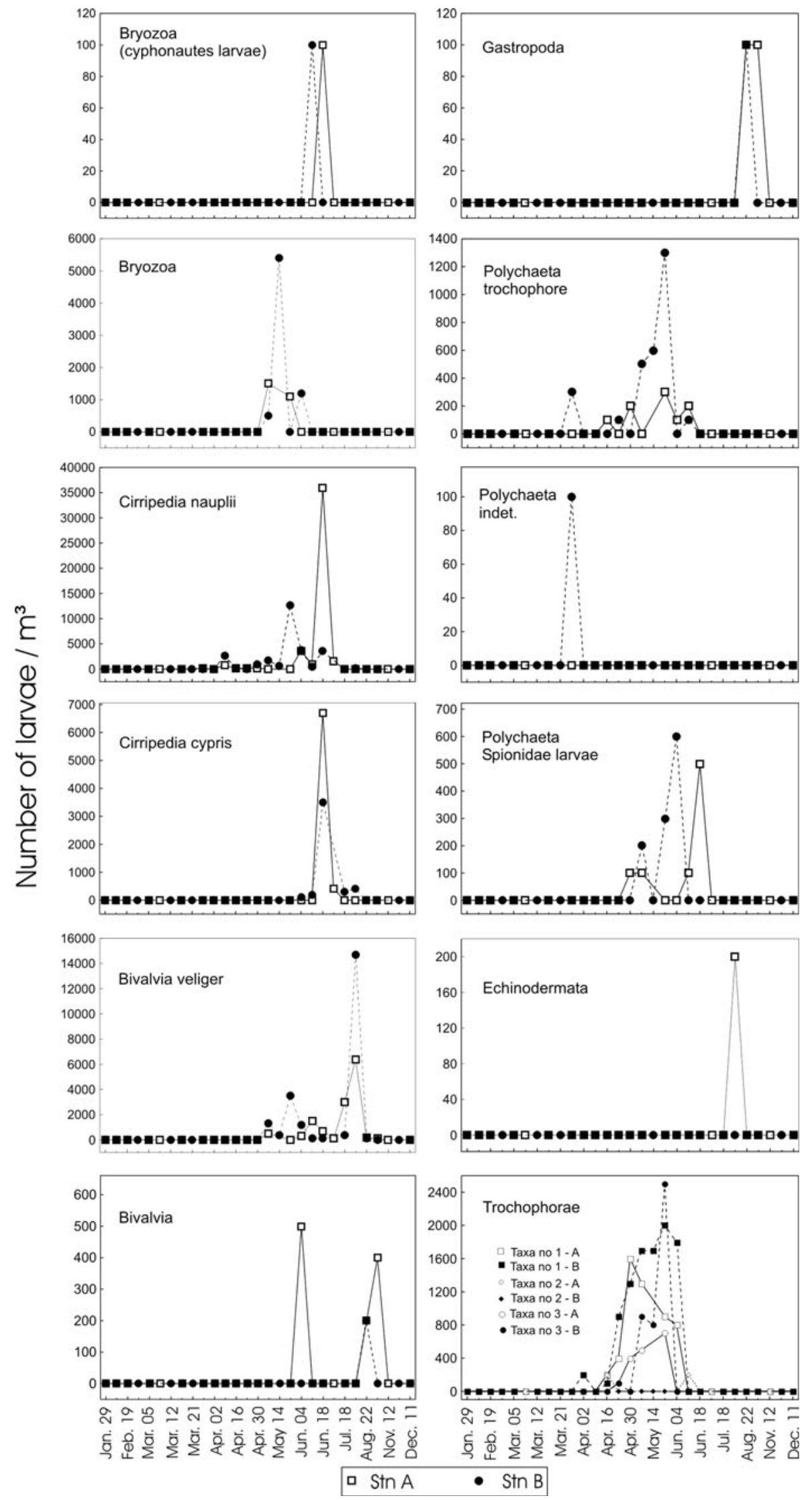




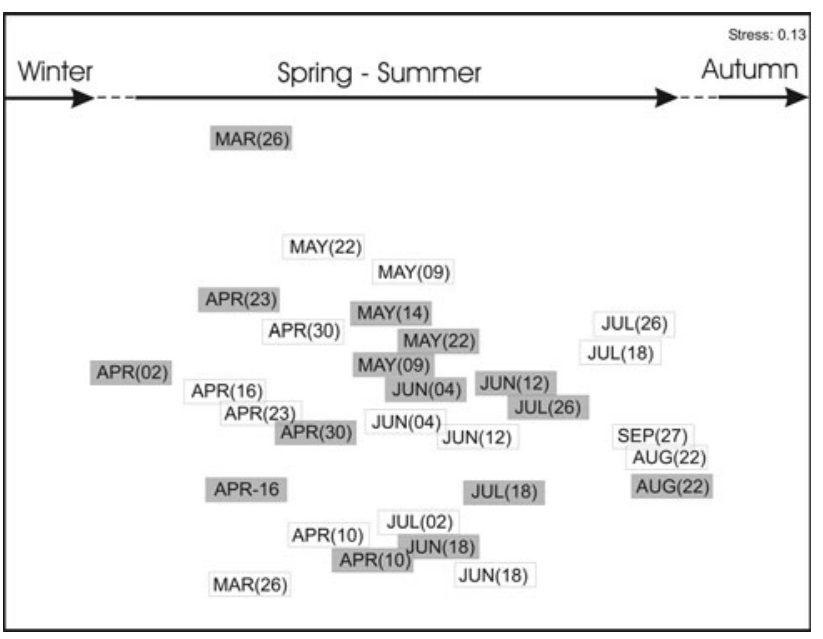

Fig. 4 Multi-dimensional scaling plot based on square root abundance data transformation of Bray-Curtis similarities between the assemblages of invertebrate larvae present in water column sampled during whole year from two locations: A (white boxes) and B (gray boxes)

parameters including particulate organic matter (POM), particulate organic carbon (POC), Chlorophyll a (Chl a), and phaeopigments (Phaeo) peaked in spring. Only dissolved organic carbon (DOC) reached its maximum in the winter. In the majority of cases, all size-fractioned measurements followed the same trends. Exceptions included POC and PON where the largest fractions $(>20 \mu \mathrm{m})$ reached their maxima in the spring, in contrast to the rest of the fractions which peaked in the summer. During the period of this study, there was no ice cover recorded at study localities.

\section{Discussion}

To our knowledge, this study is the first investigation of Arctic meroplankton occurrence over a full 1-year period in conjunction with environmental variables. Although Thorson (1936) study in Northeastern Greenland also indicated strong seasonal fluctuations in benthic larvae occurrence, but did not couple their presence with environmental conditions to the same extent as this investigation.

Our study revealed 11 meroplankton taxa in the water samples. However, based on our settlement experiment, we were able to identify a total of 22 taxa, suggesting that the number of meroplankton taxa occurring in the plankton is much higher than our water samples estimates. Some of the taxa recorded on the panels were not present in our meroplankton water samples (e.g., Hydrozoa, Ascidians) even though we collected water samples just above the sea floor. In addition, it is worth noting that some of the larvae present in the water column could belong to species which inhabit soft bottom and would never settle on the firm substrate as panels. These results might indicate that some of the species recorded on the panels may have a very narrow presence in the planktonic phase or present in the upper part of the water column. Therefore, the species may not have been captured by our water sampling schedule or near bottom water sampling or may not have originated from pelagic larvae but rather from demersal larvae developing near the panels (Thorson 1936; Mileikovsky 1971; Harvey et al. 1995). Indeed, the majority of species recorded on the control panels left at the study sites for 1 year were bryozoans, which have no feeding lecitotrophic larvae and are known to have in majority of cases demersal development (Ryland 1974). Such larvae have hardly ever previously been recorded in Arctic plankton studies, most likely owing to their near bottom demersal occurrence (e.g., Piwosz et al. 2009; Walkusz et al. 2009).

The diversity of meroplankton observed in the water column was low in comparison to other Arctic locations: 12 taxa in the White Sea (Günther and Fedyakov 2000), 42 taxa in the North Greenland fjord (Andersen 1984), 44 taxa in the Kara Sea (Fetzer and Arntz 2008). The comparatively low number could be due to the influence of the local environmental conditions. Increased temperature and decreased salinity in comparison with in situ recorded values of these parameters lowered the survival rate of spirorbid polychaete larvae from the White Sea (Ushakova 2003). Salinity levels close to 5 psu were lethal for these larvae. Adventfjorden is highly influenced by ice and freshwater discharge from rivers, which also supplies the fjord with a high level of suspended particulate matter in the summer. The high rate of freshwater discharge appears to cause a strong seasonal drop in salinity in the summer, while no ice was present throughout the period of this study (Fig. 5). Additionally, summer discharge of riverine-suspended matter may have lowered the area of hard bottom habitat suitable for settlement. Coverage by inorganic particles combined with a drop in salinity has caused a high level of osmotic stress or even mortality in benthic invertebrates in nearby fjord to our study area Kongsfjorden (Zajaczkowski and Legezynska 2001). This could lead to reduced local biodiversity, resulting in the lower observed meroplankton taxon richness.

In addition to above-mentioned factors, sampling methodology might play a role in the observed low meroplankton biodiversity. This study was based on meroplankton samples undertaken from a total volume of 340 $\mathrm{dm}^{3}$ of sea water, while Andersen (1984) investigation (42 species) was based on number of net hauls where the minimum of water sieved was $8,400 \mathrm{dm}^{3}$. Also Fetzer and Arntz (2008) (44 species) obtained samples from several locations with the minimum hauled volume of $2,652 \mathrm{dm}^{3}$.

Despite methodological limitations, this study has shown that meroplankton species richness and abundance 
Fig. 5 Concentration of suspended particles at study locality (stn C) including total particulate matter (TPM), particulate inorganic matter (PIM), particulate organic matter (POM), particulate organic carbon (POC), particulate organic nitrogen $(\mathrm{PON})$, dissolved organic carbon (DOC), Chlorophyll a (Chl a), and Phaeopigments (Phaeo) as well as sea water temperature and salinity (two last parameters were measured at station $\mathrm{A}$ )
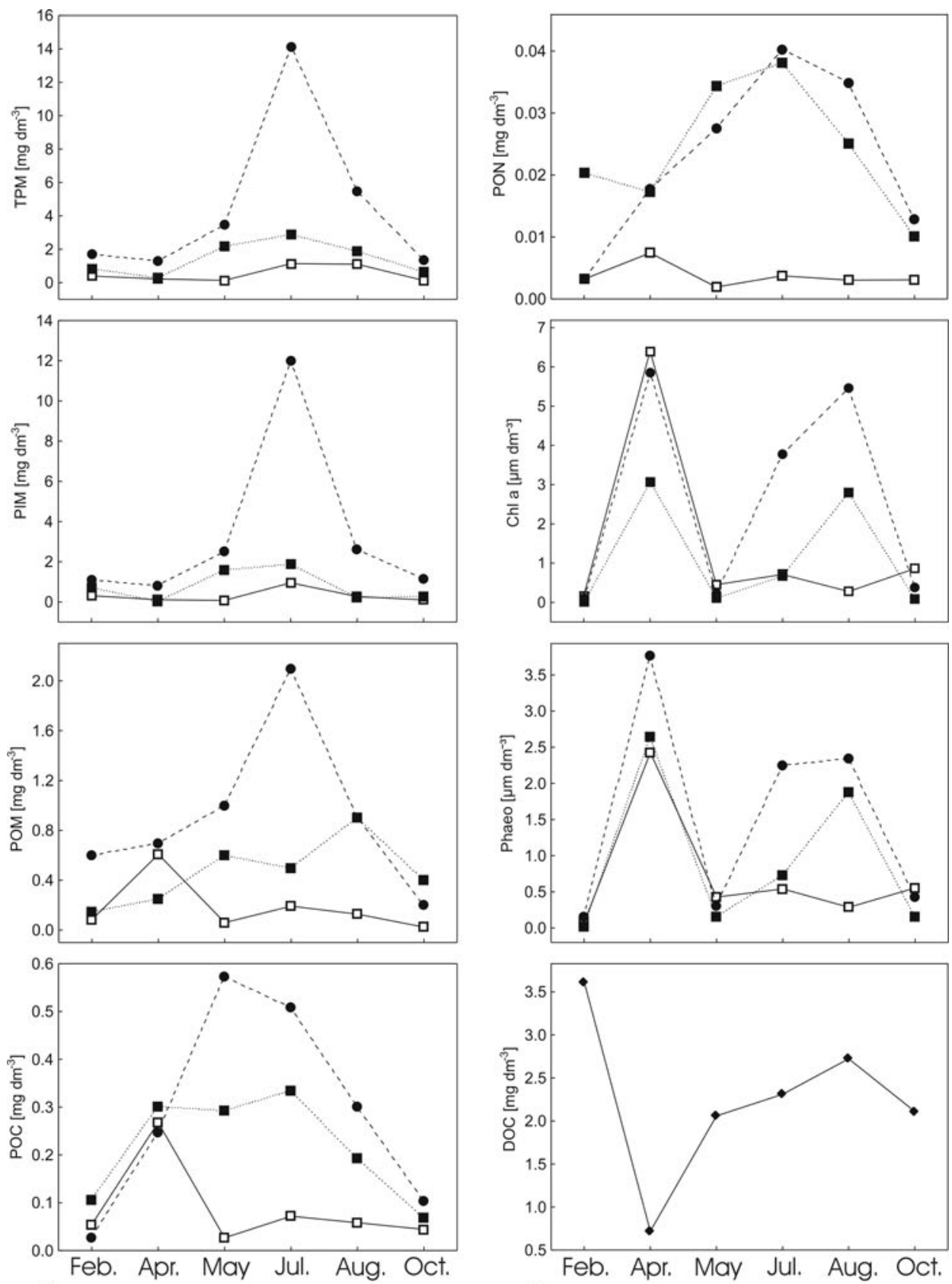

Feb. Apr. May Jul. Aug. Oct.
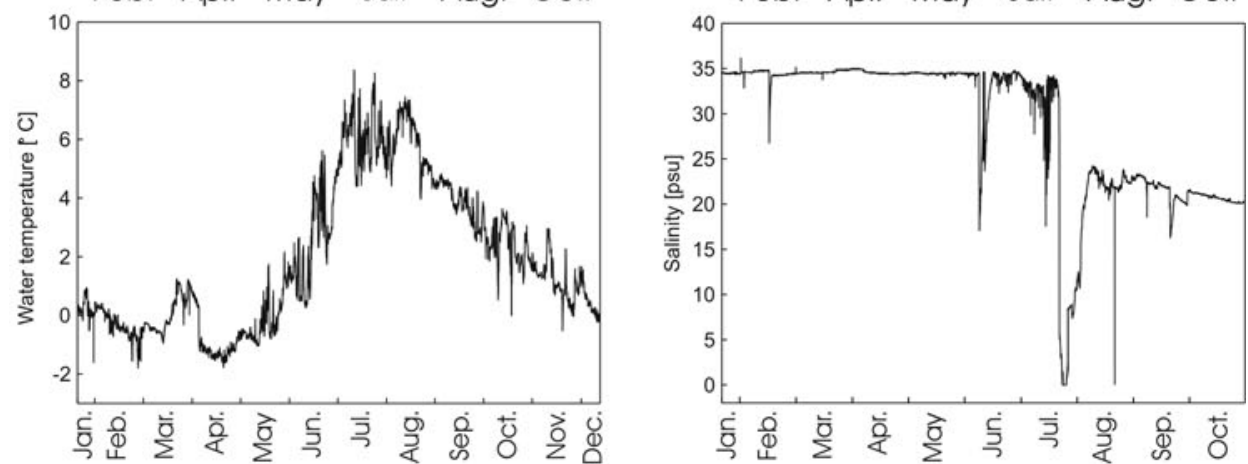

Particles size: $\quad$ व>20 $\mu \mathrm{m}$

- $2.7-20 \mu \mathrm{m}$

$0.4-2.7 \mu \mathrm{m}$ 


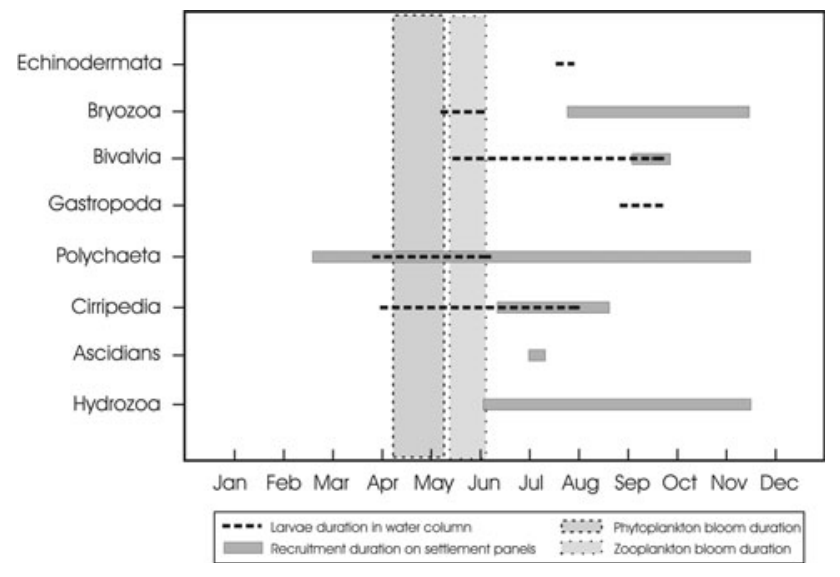

Fig. 6 Annual cycle of benthic larvae taxa present in the water column and their recruitment duration on hard substrate in relation to phyto- and zooplankton blooms

have defined seasonal pulses of occurrence during a year (Figs. 2, 3 and 6). Although meroplankton was absent from the water samples during winter months, we still observed some settlement on the panels during these months. Similar situations have been observed in other strongly seasonal systems including Northeast Greenland (Thorson 1936), the subarctic environment of Godthåbsfjord in Southwest Greenland (Smidt 1979), and the Antarctic (StanwellSmith et al. 1999; Bowden et al. 2009). It appears that larvae are present in low numbers in the water column year-round with a pronounced peak occurrence in summer months.

None of the meroplankton taxa maxima (except for bryozoan larvae) coincided exactly with the phytoplankton bloom. In the majority of cases, meroplankton were present in the water column during an abundance of other potential food sources as indicated by POM, PON, DOC, Chlorophyll a, and phaeopigments peaks rather than the phytoplankton bloom. This suggests that the timing of larval release in most taxa with planktonic larval development is coupled with the seasonal pulse of primary production, albeit not always with the main phytoplankton peak occurrence. These observations also suggest that maternal organisms might use the energy input from the phytoplankton bloom to release larvae (as income breeders), which would explain the observed delay in peak of meroplankton occurrence for some of the taxa.

Settlement on hard substrate occurs soon after the peak occurrence of meroplankton in the water column. An example of a different strategy is apparently spirorbid polychates for which we observed recruitment on the panels during the winter months. Since these organisms do not possess feeding larvae (Uschakova 2003), they are fully independent of nutrient presence in the water column. Their recruitment in winter would lower the risk of inter- specific competition for space, which may be associated with the summer peak in settlement (Fig. 2) and reduce the risk of predation. For the other Arctic meroplankton groups, especially those with planktotrophic larvae, biological parameters such as predation seem unlikely to be of a primary influence, as abundance peaks coincided with zooplankton blooms, which are believed to include the main predators of invertebrate larvae (Tönnesson and Tiselius 2005 and references therein). Well-known predatory plankton species like chaetognaths occurred in our samples in June. Therefore, in general, breeding among Arctic organisms seems to be a trade-off between fecundity and offspring survival. Several authors (e.g., Todd and Doyle 1981) have suggested that reproduction is timed to maximize food availability for the settling juveniles rather than larvae. This is particularly likely if the juveniles depend on a specific seasonally limited type or size of food. In our case, settlement of most larvae occurred later in the season (maxima in July) and in much lower quantities during winter and early spring, yet after the phytoplankton bloom (Figs. 2, 6), and therefore was not coupled with maximum food availability associated with it. A similar situation was observed in the Antarctic (Bowden 2005, Bowden et al. 2009), and it was suggested that post-settlement juveniles feed on nanophytoplankton cells present year-round in the water column.

Some studies suggest that temperature and salinity may trigger reproduction of benthic organisms, for example, in Spionids polychaeta larvae (Blake and Arnofsky 1999). Temperature increase stimulates faster development of Antarctic invertebrate larvae (Hoegh-Guldberg and Pearse 1995). Hoegh-Guldberg and Pearse (1995) suggest that this factor may override the importance of food availability. In our Arctic study, peak reproduction occurred during periods when the water temperature was highest over a prolonged period of time. During the study period, short-term temperature increases and then subsequent temperature drops were recorded in early spring (Fig. 5), yet these did not trigger any mass occurrence of meroplankton. Similarly, Thorson (1936) in Northeast Greenland and Pearse and Lockhart (2004) in Antarctica suggested that increased summer water temperature has no direct effect on timing of reproduction in marine invertebrates. It therefore appears that physical factors (water temperature and salinity) did not influence these processes directly in these areas. Yet, phytoplankton occurrence and other organic parameters associated with it (e.g., chlorophyll a) in the Arctic are triggered by a combination of certain surface irradiance values and stratification of the water column. These on the other hand are driven by a combination of water temperature and ice cover; therefore, they may have an indirect influence on meroplankton presence (Sakshaug et al. 2009). 


\section{Conclusions}

This study, as well as similar previous studies from other strongly seasonal systems (Antarctic, sub-Arctic, and other Arctic locations), found meroplankton occurrence fluctuating both in terms of taxon richness and abundance over the annual cycle. However, while in the Antarctic the planktotrophic larvae were observed throughout the year, we have not observed such a phenomenon in our investigation. Most of the meroplankton seasonal occurrence seems to be driven by spring and summer nutrient availability in the water column. However, our settlement experiment recorded recruitment also in the winter and thus further stresses that winter ecology in the high Arctic is a major gap in our current knowledge and understanding of Arctic marine ecosystems (e.g., Berge et al. 2009, 2012). Additionally, these results reveal strategies in the life history of Arctic benthic organisms. Some organisms appear to be capital breeders (Polychaeta, Cirripedia) and offspring had progressed to developmental stages that could feed to some degree on the phytoplankton bloom (Fig. 6). The adults likely use the stored energy gained before mass occurrence of phytoplankton. Some Bryozoa and Bivalvia breed directly after the phytoplankton bloom (Fig. 6). Other groups of organisms (Echinodermata, Gastropoda) have delayed breeding in relation to the phytoplankton bloom (Fig. 6). Both strategies indicate adult organisms to be income breeders or utilizing a mixture of capital and income breeding strategies regulating reproduction by food abundance. With this study, we were able to show diverse breeding strategies in Arctic benthic organisms. More detailed quantifications of the timing of reproduction in benthic organisms are necessary to obtain a broader view of Arctic life history strategies. This will require high resolution of meroplankton identification, which is often hindered by morphological limitations. New methodologies combining molecular techniques and morphological analyses will increase the accuracy of meroplankton taxonomic resolution.

Acknowledgments The authors wish to thank Suzanne "Williams," Stephen Jewett and two anonymous reviewers' for comments and corrections leading to an improved manuscript. This study has been completed thanks to a grant from the Polish Ministry of Science and Higher Education (396/N-EOL-ENC/2009/0).

Open Access This article is distributed under the terms of the Creative Commons Attribution License which permits any use, distribution, and reproduction in any medium, provided the original author(s) and the source are credited.

\section{References}

Andersen OGN (1984) Meroplankton in Jørgen Brønlund Fjord, North Greenland. Medd om Gronland 12:1-25
Berge J, Cottier F, Last KS, Varpe O, Leu E, Soreide J, Eiane K, FalkPetersen S, Willis K, Nygard H, Vogedes D, Griffiths C, Johnsen G, Lorentzen D, Brierley A (2009) Diel vertical migration of Arctic zooplankton during the polar night. Biol Let 5:69-72

Berge J, Båtnes AS, Johnsen G, Blackwell SM, Moline MA (2012) Bioluminescence in the high Arctic during the polar night. Mar Biol 159:231-237

Blake JA, Arnofsky PL (1999) Reproduction and larval development of the spioniform Polychaeta with application to systematics and phylogeny. Hydrobiologia 402:57-106

Bowden DA (2005) Seasonality of recruitment in Antarctic sessile marine benthos. Mar Ecol Prog Ser 297:101-118

Bowden DA, Clarke A, Peck LS (2009) Seasonal variation in the diversity and abundance of pelagic larvae of Antarctic marine invertebrates. Mar Biol 156:2033-2047

Bray JR, Curtis JT (1957) An ordination of the upland forest communities of southern Wisconsin. Ecol Monogr 27:325-349

Calabreses A, Davis HC (1970) Tolerances and requirements of embros and larvae of bivalve molluscs. Helgolander Wiss Meeresunters 20:553-564

Clough LM, Ambrose WG, Ashjian CJ, Piepenburg D, Renaud PE, Smith SL (1997) Meroplankton abundance in the Northeast Water Polynya: insights from oceanographic parameters and benthic abundance patterns. J Mar Syst 10:343-357

Drent RH, Daan S (1980) The prudent parent: energetic adjustments in avian breeding. Ardea 68:225-252

Fetzer I, Arntz WE (2008) Reproductive strategies of benthic invertebrates in the Kara Sea (Russian Arctic): adaptation of reproduction modes to cold water. Mar Ecol Prog Ser 356:189-202

Fetzer I, Deubel H (2006) Effect of river run-off on the distribution of marine invertebrate larvae in the southern Kara Sea (Russian Arctic). J Mar Syst 60:98-114

Grosberg RK, Quinn JF (1986) The genetic control and consequences of kin recognition by the larvae of a colonial marine invertebrate. Nature 322:456-459

Günther CP, Fedyakov FV (2000) Seasonal changes in the bivalve larval plankton of the White Sea. Senckenb Marit 30:141-151

Harvey M, Bourget E, Legault C, Ingram RG (1995) Short-term variations in settlement and early spat mortality of Iceland scallop, Chlamys islandica (O.F. Müller). J Exp Mar Biol Ecol 194:167-187

Hoegh-Guldberg O, Pearse JS (1995) Temperature, food availability, and the development of marine invertebrate larvae. Am Zool 35:415-425

IPCC (2007) Climate change 2007. The Intergovermental Panel on Climate Change 4th assessment report. www.ipcc.ch

MacGinitie G (1955) Distribution and ecology of the marine invertebrates of Point Barrow, Alaska. Smithsonian Miscellaneous Collections 128:1-201

Mileikovsky SA (1968) Distribution of pelagic larvae of bottom invertebrates of the Norwegian and Barents Sea. Mar Biol $1: 161-167$

Mileikovsky SA (1971) Types of larval development in marine bottom invertebrates, their distribution and ecological significance: a re-evaluation. Mar Biol 10:193-213

Nygård H, Wallenschus J, Varpe Ø, Camus L, Berge J (2010) Annual routines and life history of the amphipod Onisimus litoralis: sesonal growth, body composition and energy budget. Mar Ecol Prog Ser 417:115-126

Pawlowska J, Wlodarska-Kowalczuk M, Zajaczkowski M, Nygård H, Berge J (2011) Seasonal variability of meio- and macrobenthic standing stocks and diversity in an Arctic fjord (Adventfjorden, Spitsbergen. Polar Biol 34:833-845

Pearse JS, Lockhart SJ (2004) Reproduction in cold water: paradigm changes in the 20th century and a role for cidaroid sea urchins. Deep-Sea Res II 51:1533-1549 
Piwosz K, Walkusz W, Hapter R, Wieczorek P, Hop H, Wiktor J (2009) Comparison of productivity and phytoplankton in a warm (Kongsfjorden) and a cold (Hornsund) Spitsbergen fjord in midsummer 2002. Polar Biol 32:549-559

Ryland JS (1974) Behaviour, settlement and metamorphosis of bryozoan larvae: a review. Thalassia Jugoslavica 10:239-262

Sakshaug E, Johnsen G, Kovacs K (2009) Ecosystem Barents Sea. Tapir Academic Press, Trondheim, p 587

Schlüter M, Rachor E (2001) Meroplankton distribution in the central Barents Sea in relation to local oceanographic patterns. Polar Biol 24:582-592

Smidt ELB (1979) Annual cycles of primary production and of zooplankton at Southwest Greenland. Medd Grønl Biosci 1:1-53

Stanwell-Smith D, Peck LS, Clarke A, Murray AWA, Todd CD (1999) The distribution, abundance and seasonality of pelagic marine invertebrate larvae in the maritime Arctic. Proc R Soc Lond B Biol Sci 354:471-484

Stearns SC (1992) The evolution of life histories. Oxford University Press, Oxford

Thorson G (1936) The larval development, growth and metabolism of Arctic marine bottom invertebrates compared with those of other seas. Medd om Grønland 100:1-155

Thorson G (1950) Reproductive and larval ecology of marine bottom invertebrates. Biol Rev Camb Philos Soc 25:1-45

Timofeev SF (1998) Meroplankton in Spitsbergen waters. Ber Polarforsch 287:74-79

Todd CD, Doyle RW (1981) Reproductive strategies of marine benthic invertebrates: a settlement-timing hypothesis. Mar Ecol Prog Ser 4:75-83

Tönnesson K, Tiselius P (2005) Diet of chaetognaths Sagitta setosa and $S$. elegans in relation to prey abundance and vertical distribution. Mar Ecol Prog Ser 289:81-95
Ushakova O (2003) Combined effect of salinity and temperature on Spirorbis spirorbis L. and Circeus spirillum L. larvae from the White Sea. J Exp Mar Biol Ecol 296:23-33

Varpe $\varnothing$, Jørgensen C, Tarling GA, Fiksen $\varnothing$ (2009) The adaptive value of energy storage and capital breeding in seasonal environments. Oikos 118:363-370

Walkusz W, Kwasniewski S, Falk-Petersen S, Hop H, Tverberg V, Wieczorek P, Weslawski JM (2009) Seasonal and spatial changes in the zooplankton community of Kongsfjorden, Svalbard. Polar Res 28:254-281

Weslawski JM, Zajaczkowski M, Kwasniewski S, Jezierski J, Moskal W (1988) Seasonality in an Arctic fjord ecosystem: Hornsund, Spitsbergen. Polar Res 6:185-189

Weslawski JM, Kwasniewski S, Wiktor J (1991) Winter in Svalbard fiord ecosystem. Arctic 44:115-123

Willis K, Cottier F, Kwasniewski S, Wold A, Falk-Petersen S (2006) The influence of advection on zooplankton community composition in an Arctic fjord (Kongsfjorden, Svalbard). J Mar Syst 61:39-54

Zajaczkowski M, Legezynska J (2001) Estimation of zooplankton mortality caused by an Arctic glacier outflow. Oceanologia 43:341-351

Zajaczkowski M, Wlodarska-Kowalczuk M (2007) Dynamic sedimentary environments of an Arctic glacier-fed river estuary (Adventfjorden, Svalbard) I. Flux, deposition, and sediment dynamics. Estuar Coast Shelf Sci 74:285-296

Zajaczkowski M, Nygård H, Hegseth EN, Berge J (2010) Vertical flux of particulate matter in an Arctic fjord: the case of lack of the sea-ice cover in Adventfjorden 2006-2007. Polar Biol 33:223-239 